Article

\title{
Secondary School Students and Internet Forums-A Survey of Student Views Contrasted with an Analysis of Internet Forum Posts
}

\author{
Johanna Dittmar and Ingo Eilks *ii \\ Department of Biology and Chemistry-Institute for Science Education, University of Bremen, \\ Leobener Str. NW2, 28359 Bremen, Germany; johanna.dittmar@uni-bremen.de \\ * Correspondence: ingo.eilks@uni-bremen.de
}

Received: 27 March 2019; Accepted: 20 May 2019; Published: 30 May 2019

check for updates

\begin{abstract}
Students today are increasingly engaged in the use of digital information and communication technologies. The Internet continues to grow and more and more young people are using it worldwide. Educational practices, however, have been slow to adapt to the corresponding developments. For example, Internet forums are generally ignored in most educational practices, including chemistry education, although they are often used to find new information by everyday people. The question therefore arises: Why are such media not used to provoke and promote science or chemistry teaching and learning, while simultaneously developing critical scientific media literacy? To understand how the younger generation learns via Internet forums, this article looks at a survey of Internet forum usage behavior by lower and upper secondary school students (age range 12-17) in relation to chemistry-specific content. The findings are then contrasted with an analysis of user behavior. The final analysis revealed that students are open and critical when using Internet forums, even though such learning is mostly unconnected to formal education. These results can inform science and chemistry teaching by focusing teaching and learning more on Internet forums in order to employ them as an educational medium in science class.
\end{abstract}

Keywords: science education; chemistry education; interest; digital media; Internet forums

\section{Introduction}

The invention of the World Wide Web in the 1990s created the largest and most easily accessible information resource of all time. Today's Internet and social media, like Twitter, Facebook, and Internet forums, are increasingly used to communicate, to distribute and comment upon information, or to enter into dialogue [1,2]. Developments in modern information and communication technologies (ICT) have led to a continuously changing understanding of how to access and use information. The study called "Digital Life" [3] showed ten years ago that Germany's daily use of digital media included 86\% of the total population. Corresponding data for the USA, Great Britain, South Korea, and France gave numbers ranging from $70 \%$ to $80 \%$ and were slightly lower. However, these numbers have probably increased in the interim.

The use of digital tools is significant among members of the younger generation, e.g., in the case of Germany [4]. Today, almost all young people aged 12 to 19 in industrialized countries own Internet-enabled smartphones. The use of social media sites visited also grows from year to year [4]. Search engines such as Google have become the preferred access route to information [4]. Information found by Google hits, however, is not always scientifically correct and reliable. Sometimes false information is even provided to purposely mislead the public. Some sites have a chance to contribute to developing a science-based understanding of the world. Others are not so helpful. Information clearly needs to be screened and evaluated for its correctness and helpfulness [5]. 
Search engines point the way to wide-ranging resources surrounding any search term or question. In addition to news sites, corporate websites, social networks, wikis, and newspapers, discussion forums are frequently used to find information concerning a specific question. Internet forums are purposely designed to provide answers to and discussions of a given topic or question. Forums allow users to post questions, so that other people can provide more information in order to solve a problem. Questions can develop from a specific interest into bigger discussions, which continue to grow as larger numbers of people contribute. Forums seek an exchange of information, views, and beliefs among people in order to discuss the advantages and disadvantages of products, answer technical or private queries, or provide help on a given topic.

Information from Internet forums can be quite controversial, since in most cases little information can be gleaned about the contributing individuals or their level of expertise. Participants may be professionals, laymen, or people distributing false information on purpose. The assessment of information stemming from Internet forums is difficult. Consequently, today's young people need to be prepared for critical media usage. They need to be able to navigate their way through today's media in a capable, self-determined, and creative fashion, so that they can later contribute to shaping and developing media in society. Due to this, the use of new mass media by today's students provokes intense debates. This is true both in terms of educational policy and for informing classroom teaching in general. It is also the case in science or chemistry teaching in particular $[6,7]$.

This article focuses on Internet forums and their potential use in education with a special view toward chemistry education. It juxtaposes perspectives on Internet forums expressed by secondary school students (age range 12-17) over an analysis of user behavior. This allows us to identify potential starting points for dealing with Internet forums as a factor in science or chemistry education.

\section{Background}

\subsection{Digital Media and Education}

A consumer survey by Deutsche Telekom in 2009 [3] showed that an industrialized country like Germany is already thoroughly permeated by the use of digital media. Digital media and their use are largely taken for granted in people's professional and private lives. The younger generation in particular views digital media as an integral part of their existence. Many young people cannot imagine living without such media [4]. Bennett, Maton, and Kervin [8] refer to the study by Prensky [9] and reveal that all generations born after 1980 have grown up with digital media from their early years. Educational policy and classroom teaching have been suggested as areas where schools can develop new views on teaching and learning in order to deal with these "digital natives". Questions arise as to how different media experiences and skills must be taken into account, if the goal is the transformation of teaching and learning in all school subjects [7].

Bennett et al. [8] list various assumptions for investigating how adolescents deal with information technologies, including a discussion of corresponding learning styles which might be helpful. They point out, however, that most of their suggestions are not empirically proven and are often uncritically quoted. Nevertheless, some studies have described obvious changes in access to and usage behavior of digital media users, including several more-or-less clear tendencies. Based on the current pace of technological development, we must also ask ourselves how quickly studies on media usage behavior become outdated. Fifteen years ago, Kvavik, Caruso, and Morgan [10] described the majority of American learners as using computers and mobile phones, but primarily for word processing, messaging, or surfing the web. Observations in the present public space may indicate that this is still the case. This study also found that learners sometimes possess far fewer ICT skills than was assumed in previous studies [8]. This has also been described in studies in Australia [11,12]. The assumption that today's learners are much more adept at multitasking thanks to media diversity has also been refuted by Bowman, Levine, Waite, and Gendron [13]. However, surveys by Lenhart, Madden, and Hitlin [14] as well as Livingstone and Bober [15] showed that even a decade ago learners spent a lot of 
time on the Internet. These learners researched their homework or communicated with other people. The frequency and type of use depended upon the age group of the people involved. However, this did not apply to all learners alike [8].

The results presented above show the situation almost ten years ago. Meanwhile, almost every teenager in industrialized societies owns an internet-enabled mobile phone, regardless of age. Word processing programs and the exchange of messages via email are no longer the focus of surveys, since young people's media behavior has moved more solidly in the direction of social media. Research on digital media use today is more about social networks and how the younger generation is using them [4]. There are numerous studies on the use of social media for professional opportunities [1,2], experiences, and opinions about them [16-18]. There are also studies showing the influence on learning [19-21] and on specific loci like Facebook and Twitter [22,23].

While there is risk in using social media [21], the educational possibilities and chances of these new technologies have also been widely discussed. Researchers suggest that learners need to receive basic media education in school in order to develop skills for self-determined media use. UNESCO has suggested that young people need to develop competencies for dealing responsibly with all types of media on the Internet [24]. Learners should not only be able to understand and evaluate diverse information sources in the Internet [25], they should also develop skills to actively use them [7]. It is crucial to recognize "...how these platforms can enrich and diminish their personal, social, and civic lives" [21].

\subsection{Internet Forums as a Resource for Science and Chemistry Education}

The Internet is full of wide-ranging information formats. In addition to private and corporate websites, one can also find social networks, wikis, or Internet forums. An Internet forum is a platform for exchanging information between geographically-separated people [26]. The information found on forums combines facts with personal experiences, opinions, and beliefs. Forums are a question-and-answer system, which can be used at any time to get quick responses or to search earlier responses to a certain question.

There are numerous forums with different foci. These range from everyday life issues to specific professional interests. Topics concern a broad range of interests, for example, technical, scientific, political, or health-oriented forums. The more general a forum is, the larger the number of members and contributions tends to be. The more specific a forum is, the greater the chance is that people with joint interests and experiences will meet. Most Internet forums do not provide educationally reconstructed or peer-reviewed information. Only some forums offer information explicitly made for educational purposes. These sites mainly address teachers rather than students. Over the years, a plethora of questions has accumulated on Internet forums on a variety of topics with an ever-growing range of answers. Answer threads can contain anything from very short comments to very long discussions.

Some Internet forums are of interest to classroom teaching, even if they are not intended for use in formal education. They can help with homework assignments or with answering questions raised in class. They can also provide background information and highlight past discussions of situations, developments, and products found in the lesson. For example, there are many threads on the use of detergents, cosmetics, and health treatments that can be used to stimulate chemistry teaching and learning. Just as in science education [27], statements found on Internet forums also need to be reflected upon concerning their soundness and scientific validity in order to work with them responsibly. Reflection upon Internet forum entries can provide a good starting point for science teaching and learning. It can also help science education contribute to critical media education [28]. In 2005, the OECD (The Organisation for Economic Co-operation and Development) called for the use of such media in the classroom, so that learners can gain insights into the corresponding media and make them aware of the potential risks of such technologies [29].

Several studies deal with Internet forums in various ways [30-33]. There are, however, hardly any studies concerning the use of Internet forums by school students, even though relevant forums and 
forum entries for this target group appear quite often on the Internet. In German speaking countries, the website www.gutefrage.net is the largest and best-known forum and has over one million registered users. Almost 30\% of German teachers use it to prepare their lessons, thereby connecting this site directly to education [34]. Specific forums for science or even for chemistry only are normally much smaller and tend to list under 100,000 registered users [5]. Information about the popularity and use of both types of forums in (science) education, however, remains scarce.

\section{Views of Secondary Students on Internet Forums and User Behavior}

\subsection{A Questionnaire-Based Survey on How Secondary Students in Gemrany Use Internet Forums with Special Reference to Chemistry}

\subsubsection{Method and Sample}

In order to gain insight into the Internet forum usage behavior of secondary students, a questionnaire survey was carried out. It specifically focused on chemistry and related science domains. A multi-page questionnaire with open and closed (Likert-based) questions was used. The awareness of various forum types as well as participants' perceived usage behavior were examined by the questionnaire. A total of 668 secondary students (aged 12 to 17 years) from different grammar and comprehensive schools in northwestern Germany voluntarily participated in the survey. The response rate was almost $100 \%$ since data collection was operated in whole school classes during teaching time. All students had compulsory chemistry courses in school before and at the time of data collection. Three students did not provide information on their sex. Most of the analysis was performed with the aid of descriptive statistics. The open-ended questions were analyzed using qualitative content analysis according to Mayring [35].

\subsubsection{Findings}

The survey revealed that almost all of the participants were well aware of Internet forums (Figure 1), particularly the largest forum in German-speaking countries, gutefrage.net. In addition, domain-specific forums for chemistry and some educational forums were also known and listed. Domain-specific forums were, however, not so widely known. A little less than $10 \%$ of the participants were aware of these other sites. Awareness of other forums increased with age. Just over $80 \%$ of learners aged 12-14 years knew and used gutefrage.net, while almost $100 \%$ of 15 - to 17 -year-olds stated that they knew the site. The survey also revealed that most learners found forums primarily with the help of search engines and only rarely accessed them directly.

The students' answers on their usage behavior showed that learners used Internet forums in their free time (40.8\%). They also used such sites for school and homework assignments (48\% and $40.2 \%$, respectively). Forum use for homework assignments increased with age. In general, however, user behavior was almost exclusively limited to merely reading the forum threads. Only some of the older students sometimes posted questions (34.4\%). Actively answering questions in a forum was almost nonexistent for all age groups ( $85.6 \%$ chose "no answering"), thus showing a passive approach to information gathering and learning.

In order to understand which topics were pursued by students on Internet forums, we queried the students' areas of interest. Thirty possible topics were listed, which could be selected by the learners. The focus was on subjects from chemistry-related and technical fields, inspired by the ROSE (the Relevance of Science Education survey) study [36]. This included topics such as diseases and health, personal hygiene, body care products, diets, body jewelry, and healthy nutrition. Using the interest studies of Holstermann and Bögeholz [36] and Gräber and Lindner [37] as a guide, three categories were formed from the proposed topics (see Table 1). The most frequently identified topics concerned the human body ( $45.2 \%$ of the total answers) and everyday life ( $41.5 \%$ of the total answers). Issues of societal or environmental relevance were of much less interest, only comprising $13.1 \%$ of the total answers. 


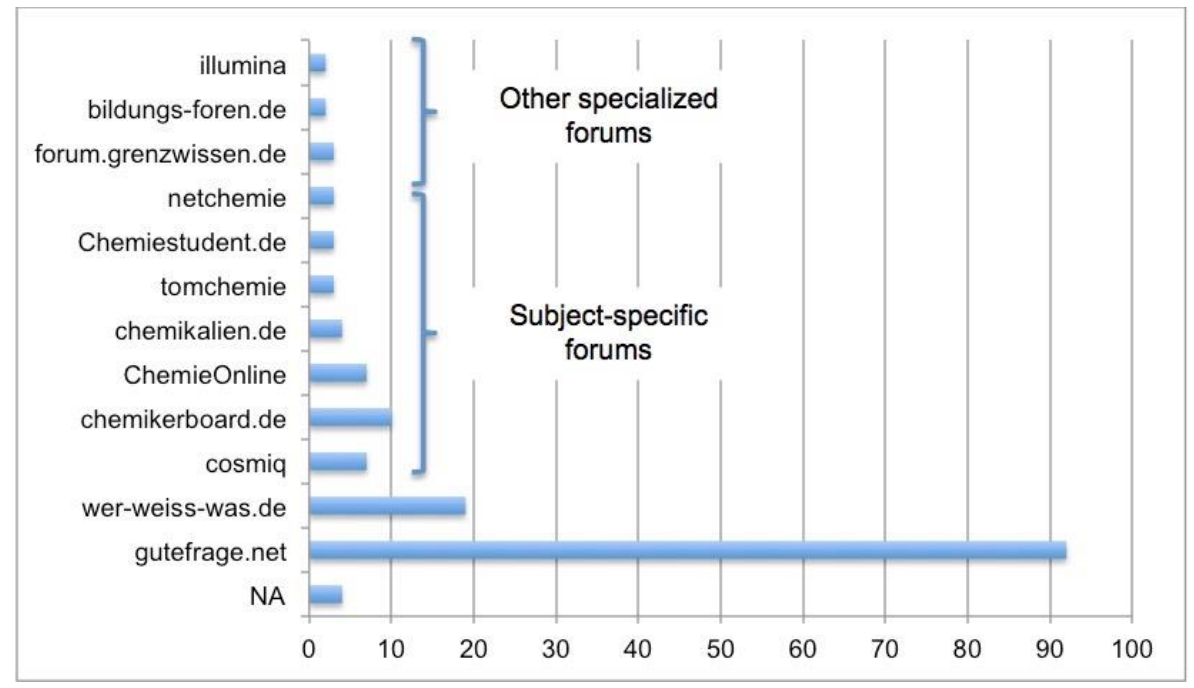

Figure 1. Awareness of general and chemistry-specific (German-language) Internet forums among young people in Germany $(\mathrm{N}=668)$.

Table 1. Interests of teenagers $(\mathrm{N}=668)$.

\begin{tabular}{|c|c|c|c|c|}
\hline & \multirow{2}{*}{ Interests } & \multicolumn{2}{|l|}{ Total } & \multirow{2}{*}{ Categories of Interest } \\
\hline & & Number & Percentage & \\
\hline 1 & Diseases and health problems & 243 & $36.4 \%$ & \multirow{14}{*}{$\begin{array}{l}\text { A1 } \\
\text { Questions about the human } \\
\text { body, e.g., nutrition, body } \\
\text { care, body awareness }\end{array}$} \\
\hline 2 & Healthy eating & 203 & $30.4 \%$ & \\
\hline 3 & Functions of the body & 154 & $23.1 \%$ & \\
\hline 4 & Personal hygiene & 145 & $21.7 \%$ & \\
\hline 5 & Sports nutrition & 131 & $19.6 \%$ & \\
\hline 6 & Body decoration & 114 & $17.1 \%$ & \\
\hline 7 & Room fragrances, perfumes, deodorants & 89 & $13.3 \%$ & \\
\hline 8 & $\begin{array}{l}\text { Compatibility of personal care products, } \\
\text { creams }\end{array}$ & 77 & $11.5 \%$ & \\
\hline 9 & Ingredients and effects of drugs & 77 & $11.5 \%$ & \\
\hline 10 & Diets, sweeteners & 75 & $11.2 \%$ & \\
\hline 11 & Dental care, teeth cleaning, whitening & 71 & $10.6 \%$ & \\
\hline 12 & Sweets & 60 & $9 \%$ & \\
\hline 13 & Composition of food and drink & 56 & $8.4 \%$ & \\
\hline 14 & Food additives & 47 & $7 \%$ & \\
\hline 15 & Explosives, poisons & 117 & $17.5 \%$ & \multirow{7}{*}{$\begin{array}{l}\text { A2 } \\
\text { Issues of importance to } \\
\text { society and the environment, } \\
\text { e.g., chemicals, } \\
\text { environmental awareness, } \\
\text { occupations }\end{array}$} \\
\hline 16 & Toxic substances in everyday products & 100 & $15 \%$ & \\
\hline 17 & Environmental issues & 81 & $12.1 \%$ & \\
\hline 18 & Effects of chemicals in the environment & 58 & $8.7 \%$ & \\
\hline 19 & Energy generation & 49 & $7.3 \%$ & \\
\hline 20 & Seals of approval & 25 & $3.7 \%$ & \\
\hline 21 & Packaging material and recycling & 18 & $2.7 \%$ & \\
\hline 22 & $\begin{array}{l}\text { Electronics, mobile phones, computers, } \\
\text { electronic waste }\end{array}$ & 400 & $59.9 \%$ & \multirow{9}{*}{$\begin{array}{l}\text { A3 } \\
\text { Questions about everyday } \\
\text { life, e.g., technique, clothing, } \\
\text { animals, knowledge, } \\
\text { applications with benefits, } \\
\text { miscellaneous }\end{array}$} \\
\hline 23 & Animals and pets & 219 & $32.8 \%$ & \\
\hline 24 & Dress & 182 & $27.2 \%$ & \\
\hline 25 & Sports equipment & 174 & $26 \%$ & \\
\hline 26 & Cars, traffic, bicycles, trains & 167 & $25 \%$ & \\
\hline 27 & Alcohol, cigarettes, drugs & 132 & $19.8 \%$ & \\
\hline 28 & Plastics & 70 & $10.5 \%$ & \\
\hline 29 & Planting and gardening & 40 & $6 \%$ & \\
\hline 30 & Functional clothes & 32 & $4.8 \%$ & \\
\hline
\end{tabular}


We found that the participants generally view answers on Internet forums as comprehensible, helpful, and trustworthy. However, almost $50 \%$ of learners also assumed that posts on forums are sometimes of low quality and need to be viewed critically.

Young peoples' perception in dealing with Internet forums (see Figure 2) was determined by an open-ended question in the questionnaire. Learner responses were evaluated with the help of Mayring [35]. We assigned answers to high-, medium-, and low-acceptance categories. In addition, critical comments within these categories were identified in the use of Internet forums.

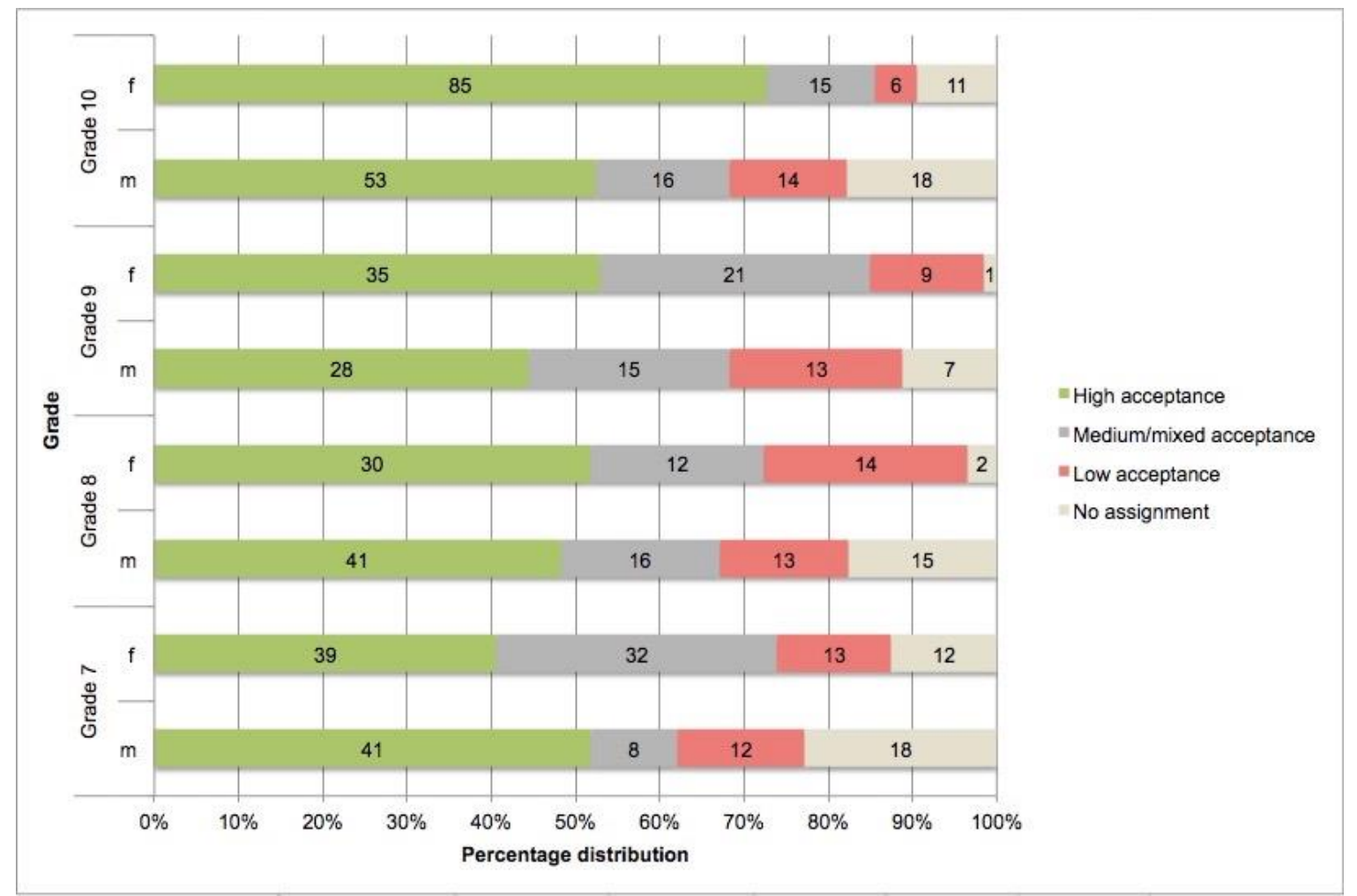

Figure 2. Acceptance of forum posts by teenagers $(\mathrm{N}=668$; spread in percentage distribution, numbers in bars give the absolute numbers).

Within the age groups, the acceptance of Internet forums was different (Figure 2). Almost half of students between the ages of 12 and 13 showed a high degree of acceptance of information from Internet forums. However, female students $(40 \%)$ showed less acceptance at face value than did male students (51.8\%). Both sexes were equally critical when it came to trusting Internet forums; "Internet forums can help a lot with questions, but sometimes I think that they can be wrong". Among 14- to 15-year-olds, more female students showed a high level of acceptance of Internet forums (51.7\%), but the girls also showed a much more critical stance toward the forums than did the boys. A typical remark was "If there is a question, there are several answers, if one does not understand. The downside is that everyone can answer there. Therefore, no guarantee exists that everything is right. But it is convenient that if you enter your question on google.de, the forums are displayed with the appropriate answers to your question". The 16-year-old female students finally showed a high degree of acceptance in dealing with Internet forums (61.5\%), while the overall level dropped below $40 \%$ for the students in this age group. There seems to be a slight decrease in high acceptance among boys and an increase among girls. A sound explanation for both of these trends was, however, not identified in the data. It became apparent with the open-ended questions that the learners already recognized the potential advantages of Internet forums, but also faced insecurity in dealing with them. In addition to the many and varied answers, the learners recognized the fact that anyone can write an answer in Internet forums. They realized that there is therefore no absolute guarantee that the answers come from experts. 
It is possible that they can also be based on the mere personal experience of a layman, or even be faked on purpose.

\subsection{A Showcase Analysis of the Most Popular German Language Internet Forum, Gutefrage.net, with a Special View Toward Chemistry Education}

\subsubsection{Method and Sample}

The purpose of this case was to investigate how helpful forum posts are perceived by users and how varied answers to a question are. The analysis focused on the most common Internet forum in German language, gutefrage.net. This popular site is a general, free forum in which only registration is necessary for active participation. After registration, all functions on the forum are open to all users. This includes, among other things, the internal evaluation of member contributions. Helpful answers and compliments can be rated, rewarding the forum writers with points and titles. For example, if a forum writer has given 50 helpful answers, this person is credited with the title of "expert". However, this award is time-limited and loses its validity if the commitment and quality if the contributions diminish over time. Other internal guidelines at gutefrage.net [38] also include the possible reasons for asking a question. Thus, contributions may be presented as questions of knowledge, local or regional questions, questions of discussion and opinion, or questions requiring advice. In addition, queries can be assigned to different subject areas, but these areas are not prescribed. Each of the collected threads consists of one question with the associated answers and comments. Answers are marked as "most helpful answer" or "expert answer".

Over a period of eight weeks, screenshots of the first twenty consecutive threads in gutefrage.net were collected on one day of the week at a specific time [30,32]. Data collection yielded a sample of 160 random questions and 718 associated answers. Analysis was performed using document analysis [39].

Based on these screenshots, we first identified the number of questions, helpful answers, expert answers, and unanswered questions. The threads were then assigned to specific topics. This was again based on the categories formed according to the interest studies carried out by Bögeholz and Holstermann [36] and Gräber and Lindner [37]:

- A1: Questions about the human body (nutrition, body care, body awareness, etc.);

- A2: Issues of importance to society and the environment (chemicals, environmental awareness, occupations, etc.);

- $\quad$ A3: Questions about everyday life (clothes, animals, sports, mobility, etc.).

The number of answers was determined descriptively. A percentage distribution was then calculated to allow for comparisons. The mean and the variance were determined to define the coding of the responses using intervals. In order to categorize these intervals, the questions from the threads were examined for similarity with the help of Mayring [35]. In addition to identification of the topics, the motivation of the inquirer was determined for the respective research question (taking into account the motivation categories from gutefrage.net [40]). Potential motives for a question included confirmation, information, correction, opinion (after experience or treatment), problem-solving, or a targeted or open search.

\subsubsection{Findings}

Of the 160 questions total, $69 \%$ referred to issues that are within the focus of this study. Overall, $48 \%$ of the questions were about everyday issues, $15 \%$ about the human body, and $6 \%$ about science-related societal or environmental content. The other questions concerned private topics. Typical private questions of younger authors related to people of the opposite sex and the associated interpersonal problems. A second large category included tips for playing computer games. Older forum writers often referred to problems in their family or asked for holiday destination information.

Everyday questions in relation to science and technology often focused on technical issues. A total of $67 \%$ of the questions regarded problems with the use of digital media. For example, younger 
contributors often asked for help on the installation of computer games or on technical issues to help them enhance their gaming experiences. Older forum authors asked about "internet performance", the pros and cons of certain computer devices, or other technical issues. The same applied to mobile phones, although fewer questions were found in this area. In the field of society and environment, only job-related content was presented for discussion. For example, users asked if a document was a "good professional assessment", or how many semesters are necessary to complete a degree program. This included the experiences of outsiders entering a totally different profession. Questions about chemicals or environmental awareness were not asked in this survey. The area of the human body focused on issues dealing with body awareness. These were very often health problems. Physical problems were often described. Users asked about the experiences of other people having similar problems. We found that $33 \%$ of the forum questions gave answers that were rated as helpful or expert, for a total of 160 questions. Only $6 \%$ of the inquiries remained unanswered (Figure 3). Of the helpful answers, $83 \%$ concerned questions about everyday life, 13\% about the human body, and $4 \%$ were job-related questions.

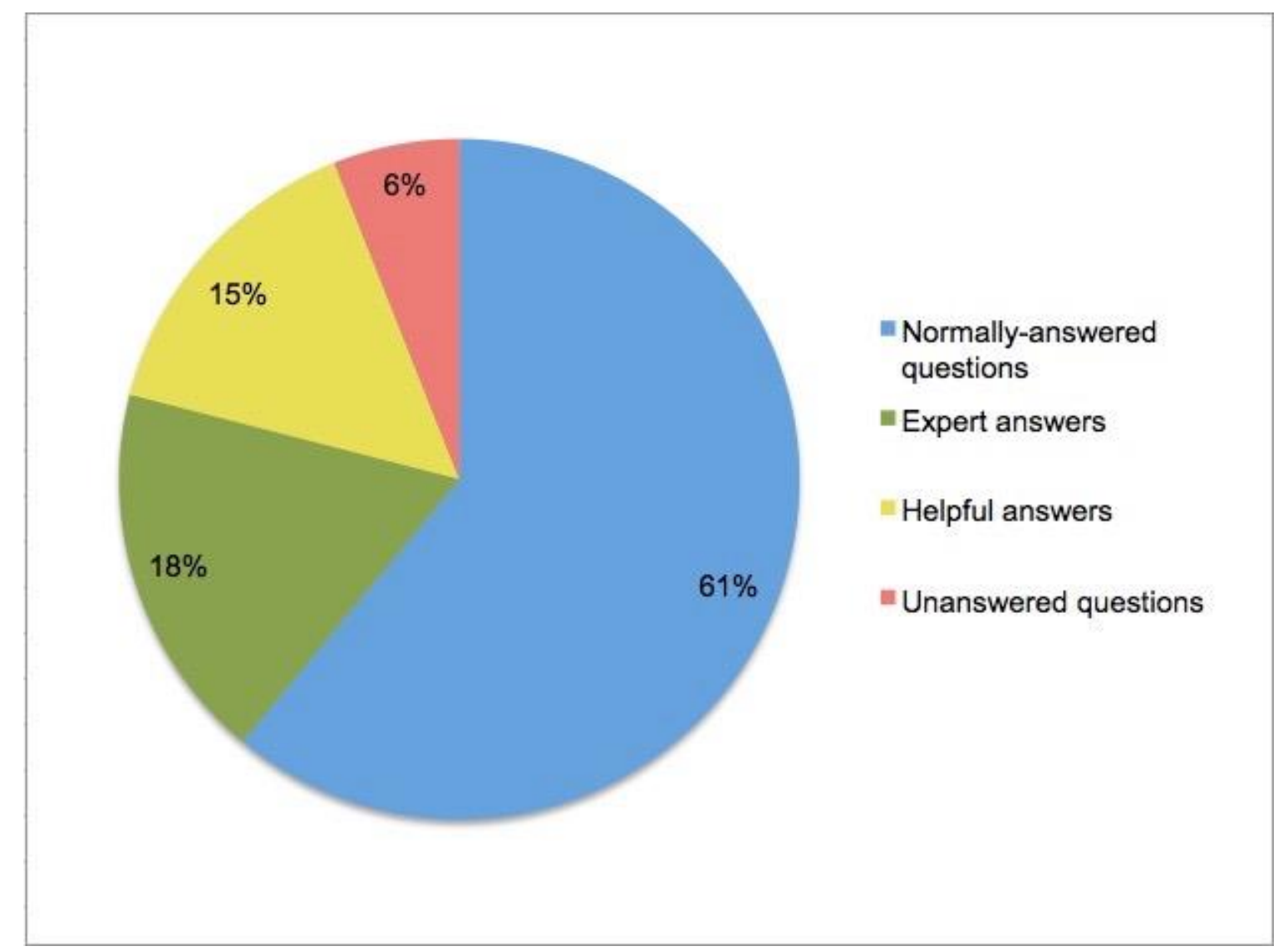

Figure 3. Comparison of helpful and expert answers to unanswered questions (in \%).

Seventy-five percent of the expert answers concerned questions about everyday life, followed by questions about the human body (25\%). There were no expert answers to any of the professional questions. The unanswered questions were all related to everyday issues, with $70 \%$ relating to technical issues and $30 \%$ to other issues.

In the descriptive evaluation of the response yields (answers per question), the mean value was determined to be 5.3 and the sample variance was 7.81 . This measure was used to divide the response yields into intervals, resulting in the partitioning shown in Table 2. 
Table 2. Intervals of response yields.

\begin{tabular}{ccc}
\hline \multicolumn{3}{c}{ Response Yields } \\
\hline $\mathrm{X}=0$ & unusable yield & $\mathrm{K} 0$ \\
$0<\mathrm{X}<5$ & low yield & $\mathrm{K} 1$ \\
$\mathrm{X}=5$ & average yield & $\mathrm{K} 2$ \\
$5<\mathrm{X}<14$ & high yield & $\mathrm{K} 3$ \\
$\mathrm{X}>13$ & very high yield & $\mathrm{K} 4$ \\
\hline
\end{tabular}

An average yield (five answers to a question) occurred in $11 \%$ of the total questions. Almost half of all questions received between one and four answers. A high yield of answers was seen in $21 \%$ of the total questions. Six percent of the questions did not receive any answers and $3 \%$ had more than thirteen answers. Within the individual response yields, the descriptive evaluation showed that most helpful and expert answers were given in the mean response yield (Figure 4). The numbers of helpful and expert answers decreased in the lowest and highest response yield categories.

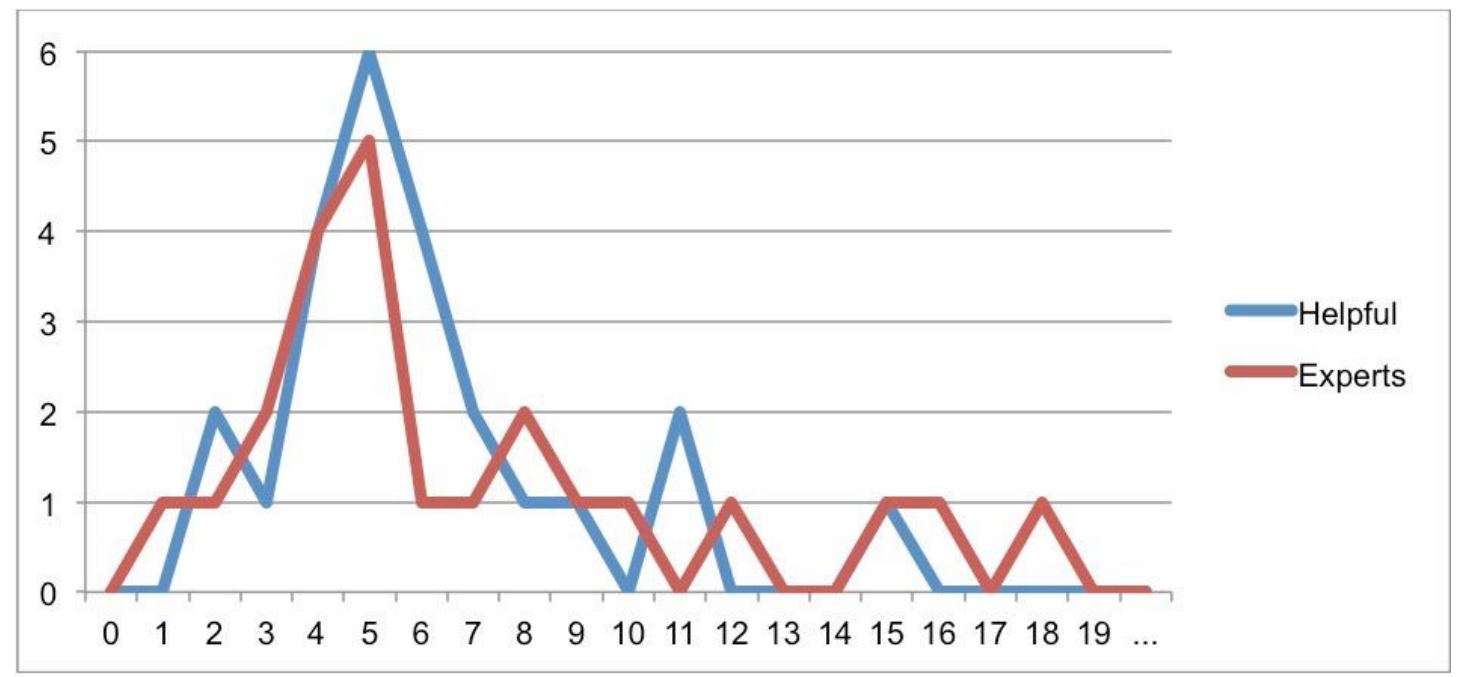

Figure 4. Distribution of helpful and expert answers to the response yields.

In analyzing the potential motivations of forum writers, six categories were identified, with three of them being dominant. Most of these questions requested opinions from other forum members or asked general information to increase personal knowledge through facts. Questions that required concrete solutions to problem situations could also be identified more frequently. Queries submitted for the purposes of confirmation, correction, or general searching were only represented by a small percentage. The distribution, however, depended on the response yield of a question (Figure 5). Concrete answers, e.g., on troubleshooting, were dominant in shorter threads. After a problem was solved there was no more need for further entries. The longer a thread was, the greater the exchange of opinions became. This is probably because factual information and concrete help had already been exchanged and the question started an open discussion. 


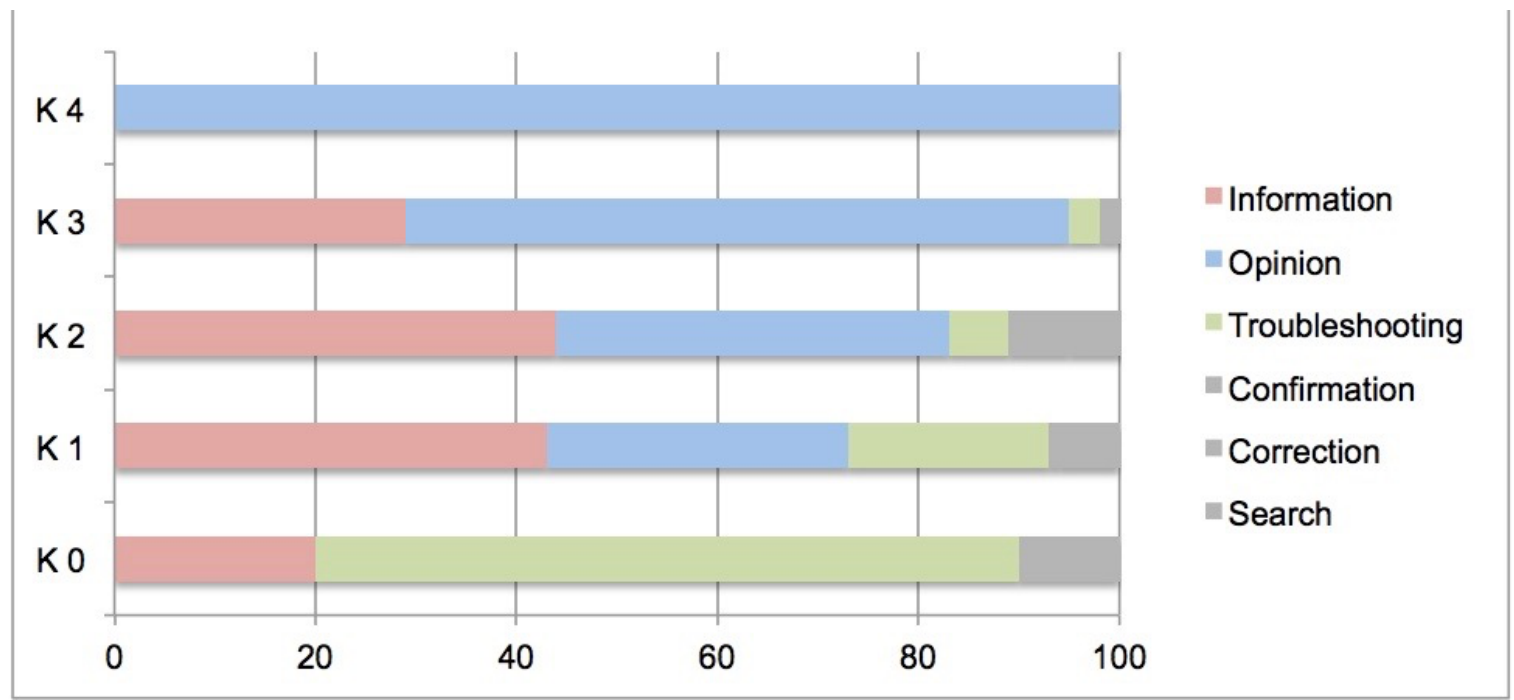

Figure 5. Reasons for questions in relation to the response yield.

\section{Discussion and Conclusions}

An Internet forum is a technical tool that can be used to find information or to solve problems, in other words, to learn. However, students need to recognize and reflect upon an Internet forum's usefulness and user-friendliness if they are asked to learn with the help of Internet sources [41]. Internet forums correspond to a specific design and organization of information. General forums have different characteristics than domain-specific forums. In contrast to general forums, domain-specific forums are much more focused and sometimes provide more abstract and complex information and answers, e.g., in chemistry. Internet forums of different types are also likely to vary widely in their response yields. In our analysis we found that there are different answer yields depending on the purpose of a question. A response yield with five answers yielded the most answers rated as helpful or expert. One might come to the conclusion that a response yield of five answers may therefore be an ideal response yield. However, this should be viewed with caution, because any answer yield may have advantages or disadvantages depending on the motive of the initial question. This might be abstract to further analysis.

General forums yield a demonstrable majority of questions requiring opinions or information, but specialized forums are more likely to contain more frequent questions requiring single solutions, confirmation, or correction. In this case, precise and short answers might be more helpful for guiding someone through a problem. Questions requiring discussion tend to have rather high response yields, which are generally desirable in this case. This certainly depends upon the discipline. Thus, it is important that students understand the organization and the different types of Internet forums. They also need to be able to estimate the motive of a given question and be in a position to select the proper forum to use. For this reason, it is important that learners become aware of the possibilities offered by domain-specific Internet forums. This might reduce learners' insecurity in dealing with both type of forums and increase the perceived ease of use. The existence of different forums to choose from can help learners avoid being automatically routed to the most popular general forums by search engines.

This paper chose the best-known forum in the German language, gutefrage.net. This site is well-known by almost all secondary students in Germany. However, domain-specific forums, e.g., forums on chemistry, are much less known. Learners' awareness of Internet forums is generally high, even at lower age and class levels. This increases with age. Internet forums are widely used, but also viewed somewhat critically by secondary school students when it comes to the quality of the forum posts. Nevertheless, Internet forums are viewed as helpful among secondary school students, even if learners admit to some insecurity in assessing the quality of the answers found. The analysis of gutefrage.net found that most questions directed to a forum audience concerned the everyday lives of 
the users or the human body. These are very often not general questions, but rather concrete problems, such as disease or disability, for which specific answers and opinion-based replies are sought. We could discern that questions only seeking information or general opinions tend to be particularly successful in terms of diverse and helpful answers in the Internet. If we compare this to learner motives in formal educational contexts that might be better researched in the future, we might better recognize a discrepancy which might explain why so few students use Internet forums to support their formal learning in school.

The questionnaire study showed that only a relatively small portion of learners use Internet forums to help with homework assignments or school learning. There seem to be completely different motivations which lead students into forums like gutefrage.net. Most probably, they expect help with everyday life issues but would not expect to receive satisfactory answers for problems with school lesson content. In order to meet learners' school-based questions, specialized Internet forums would have to be visited. Especially in the sciences, there are numerous forums which focus on chemistry and other domains [5]. These forums also take into account school lesson content, however, they are rarely used by the students. Curriculum development and research might reveal whether this situation would change if domain-specific forums were introduced in science classes.

In a subject-specific forum, the likelihood of finding experts in the field might be much higher, as is the chance of receiving a profitable answer or constructive help in solving a technical problem. In the analysis described in this paper, the unanswered questions in gutefrage.net pertained mainly to very specific technical questions concerning computer use. Perhaps the choice of this forum for such issues was unsuitable. A better or more profitable answer might have been gained by posting these questions in a computer-focused forum. We saw above that the choice of a proper forum can improve work performance, thereby increasing the perceived usefulness of a site [41,42]. The same might hold true if formal education introduced students to domain-specific forums and showed them how to benefit from such resources, e.g., in school chemistry education.

Internet forums have barely been taken into consideration as tools to be used in formal science education [5]. Further research might reveal the reasons, e.g., by analyzing the teachers' perspective on the use of social media in science classes. Forums have great potential to promote both learning and teaching, e.g., in chemistry lessons. The interests of secondary students in Internet forums largely overlap with the findings of interest studies (e.g., [36]). Conversely, Internet forums can provide teachers with information about their students' interests. There have also been initial, practical suggestions of using a Moodle forum in chemistry teaching as a communication tool between student groups for cooperative learning [28]. Learners would not only get to know Internet forums as a source of information, but also engage in discussions on issues related to science and technology via online forums. In this case, the task of writing a professionally sound answer is added to the need to critically scrutinize the contributions of other groups. Learners should experience dealing actively with an online forum and get to know it as a constructive medium. Likewise, they should be made aware that statements can be either right or wrong. They must be able to understand that responses in the case of opinions come from different personal perspectives and do not necessarily represent absolute truth. Such an approach might help students to start actively working with Internet forums, instead of being just passive consumers of information and opinions. Research, however, needs to reveal whether and how this approach would work.

Internet forums are well known to most learners. They can provide authentic learning contexts for science classes, both with their content matter and in their use as authentic everyday practices of communication and information exchange. Everyday problems can be introduced into the classroom via Internet forum posts to spur research and discussion, e.g., on which chemical products are safe or environmentally benign. Authentic Internet forum threads can be used to question responses critically and to reflect upon how others explain something, e.g., whether scientific facts and arguments are used properly. Proof of scientific claims can even be made subject to the learning of new theories or practical work. They can also highlight whether a question is answered in a scientifically correct or 
incorrect manner, e.g., when Internet posts mix up scientific concepts with alternative, non-reliable arguments. Intergroup discussions via online forums can link learning groups from different schools. This will probe what others think about specific issues related to science and technology, e.g., when discussing the question regarding whether bottled mineral water is of better quality than tap water [28]. It can also help the class determine whether it wants to personally contribute to a forum thread with the knowledge the students developed while they learned. Authenticity and real-life scenarios have been suggested as reasons to raise student perception of the relevance of education [43]. The use of Internet forums to discuss real life issues and teach practices widely used on the Internet might aid in strengthening students' personal perceptions of the relevance of science education in general and chemistry education in particular.

Author Contributions: Conceptualization, J.D.; methodology, J.D. and I.E.; validation, J.D. and I.E.; formal analysis, J.D.; investigation, J.D.; data curation, J.D.; writing—original draft preparation, J.D.; writing-review and editing, J.D. and I.E.; project administration, I.E.

Funding: This research received no external funding.

Conflicts of Interest: The authors declare no conflict of interest.

\section{References}

1. Donelan, H. Social media for professional development and networking opportunities in academia. J. Furth. High. Educ. 2015, 40, 706-729. [CrossRef]

2. Li, J.; Greenhow, C. Scholars and social media: Tweeting in the conference backchannel for professional learning. Educ. Med. Int. 2015, 52, 1-14. [CrossRef]

3. Deutsche Telekom, AG. LIFE—Digitales Leben [LIFE—Digital Life]. 2009. Available online: www.studie-life. de (accessed on 23 July 2018).

4. MFPS JIM-Studie 2016 [JIM-Study 2016]. 2006. Available online: www.mpfs.de/fileadmin/files/Studien/JIM/ 2016/JIM_Studie_2016.pdf (accessed on 22 January 2017).

5. Dittmar, J.; Eilks, I. Internetforen-Eine bislang kaum erschlossene Quelle für den naturwissenschaftlichen Unterricht [Internet forums-A hardly opened resource for science teaching]. Math. Naturwiss. Unterr. 2015, $68,213-217$.

6. Chang Rundgren, S.-N.; Rundgren, C.J. Making chemistry education relevant through mass media. In Relevant Chemistry Education —From Theory to Practice; Eilks, I., Hofstein, A., Eds.; Sense: Rotterdam, The Netherlands, 2015; pp. 205-218.

7. Belova, N.; Dittmar, J.; Hansson, L.; Hofstein, A.; Nielsen, J.A.; Sjöström, J.; Eilks, I. Cross-curricular goals and the raise of the relevance of science education. In Cognitive and Affective Aspects in Science Education Research; Hahl, K., Juuti, K., Lampiselkä, J., Lavonen, J., Uitto, A., Eds.; Springer: Dordrecht, The Netherlands, 2017; pp. 297-307.

8. Bennett, S.; Maton, K.; Kervin, L. The 'digital natives' debate: A critical review of the evidence. Br. J. Educ. Technol. 2008, 39, 775-786. [CrossRef]

9. Prensky, M. Digital natives, digital immigrants. Horizon 2001, 9, 1-6.

10. Kvavik, R.B.; Caruso, J.B.; Morgan, G. ECAR study of students and information technology. In Convenience, Connection and Control; EDUCAUSE Center for Applied Research: Boulder, CO, USA, 2004.

11. Kennedy, G.; Krause, K.; Judd, T.; Churchward, A.; Gray, K. First year students' experiences with technology: Are they really digital natives. Australas. J. Educ. Technol. 2008, 24, 108-122. [CrossRef]

12. Oliver, B.; Goerke, V. Australian undergraduates' use and ownership of emerging technologies: Implications and opportunities for creating engaging learning experiences for the net generation. Australas. J. Educ. Technol. 2007, 23, 171-186. [CrossRef]

13. Bowman, L.L.; Levine, L.E.; Waite, B.M.; Gendron, M. Can students really multitask? An experimental study of instant messaging while reading. Comp. Educ. 2010, 54, 927-931. [CrossRef]

14. Lenhart, A.; Madden, M.; Hitlin, P. Teens and Technology: Youth Are Leading the Transition to a Fully Wired and Mobile Nation; Pew Internet \& American Life Project: Washington, DC, USA, 2005.

15. Livingstone, S.; Bober, M. Taking up online opportunities? Children's use of the Internet for education, communication and participation. E-Learn 2004, 1, 395-419. [CrossRef] 
16. Uusiaautti, S.; Määtä, K. I am no longer alone-How do university students perceive the possibilities of social media? Int. J. Adolesc. Youth 2014, 19, 293-305. [CrossRef] [PubMed]

17. Lu, J.; Churchill, D. The effect of social interaction on learning engagement in a social networking environment. Interact. Learn. Environ. 2014, 22, 401-417. [CrossRef]

18. Arquero, J.L.; Romeo-Frias, E. Using social network sites in higher education: An experience in business studies. Innov. Educ. Teach. Int. 2013, 50, 238-249. [CrossRef]

19. Balakrishnan, V. Using social networks to enhance teaching and learning experiences in higher learning institutions. Innov. Educ. Teach. Int. 2014, 51, 595-606. [CrossRef]

20. Vasbø, K.B.; Silseth, K.; Erstad, O. Being a learner using social media in school: The case of space2cre8. Scandinavien. J. Educ. Res. 2014, 58, 110-126. [CrossRef]

21. Krutka, D.G.; Carpenter, J.P. Why social media must have a place in schools. Kappa Delta Pi Rec. 2016, 52, 6-10. [CrossRef]

22. Donlan, L. Exploring the views of students on the use of Facebook in university teaching and learning. J. Furth. High. Educ. 2014, 38, 572-588. [CrossRef]

23. McPherson, M.; Budge, K.; Lemon, N. New practices in doing academic development: Twitter as an informal learning space. Int. J. Acad. Dev. 2015, 20, 126-136. [CrossRef]

24. UNESCO. Wissen im Web 2008. Available online: www.unesco.de/fileadmin/medien/Dokumente/unescoheute/unesco-heute-1-08.pdf (accessed on 2 January 2017).

25. Marks, R.; Stuckey, M.; Belova, N.; Eilks, I. The societal dimension in German science education-From tradition towards selected cases and recent developments. Eurasia J. Math. Sci. Technol. Educ. 2014, 10, 285-296. [CrossRef]

26. Wolff, T. Was Schüler im Internet Tun; [What Students Do in the Internet]; Beltz: Weinheim, Germany, 2011.

27. Belova, N.; Eilks, I. Learning with and about advertising in chemistry education with a lesson plan on natural cosmetics-A case study. Chem. Educ. Res. Pract. 2015, 16, 578-588. [CrossRef]

28. Dittmar, J.; Eilks, I. Practical work, cooperative learning and Internet forums-An example on teaching about the chemistry of water. In Science Education Research and Practical Work; Eilks, I., Markic, S., Ralle, B., Eds.; Shaker: Aachen, Germany, 2016; pp. 39-244.

29. OECD. The Definition and Selection of Key Competencies 2005. Available online: https://www.oecd.org/ pisa/35070367.pdf (accessed on 15 May 2017).

30. Mitchell, J.T.; Sweitzer, M.M.; Tunno, A.M.; Kollins, S.H.; McClernon, F.J. “I Use Weed for My ADHD”: A qualitative analysis of online forum discussions on cannabis use and ADHD. PLoS ONE 2016, 11, e0156614. [CrossRef]

31. Franke, N.; Hienerth, C. Prädikatoren der Qualität von Geschäftsideen: Eine empirische Analyse eines Online-Ideen-Forums [Predictors and quality of business iedas: An empirical analysis of an online-idea-forum]. Z. Betriebswirt. 2006, 76, 47-68.

32. Cole, J.; Watkins, C.; Kleine, D. Health advice from Internet discussion forums: How bad is dangerous? J. Med. Internet Res. 2016, 18, e4. [CrossRef] [PubMed]

33. Bourgonjon, J.; Vandermeersche, G.; De Wever, B.; Soetaert, R.; Valcke, M. Players' perspectives on the positive impact of video games: A qualitative content analysis of online forum discussions. New Media Soc. 2015, 18. [CrossRef]

34. Statista. Anteil der Nutzung von Online-Angeboten durch Lehrer für den Schulunterricht in Deutschland im Jahr 2016. Available online: de.statista.com/statistik/daten/studie/180369/umfrage/nutzungvon-onlineangeboten-im-unterricht/ (accessed on 19 December 2014).

35. Mayring, P. Qualitative Content Analysis: Theoretical Foundation, Basic Procedures and Software Solution; Gesis: Mannheim, Germany, 2014.

36. Holstermann, N.; Bögeholz, S. Interesse von Jungen und Mädchen an naturwissenschaftlichen Themen am Ende der Sekundarstufe I [Interest of boys and girls on scientific issues at the end of lower secondary education]. Z. Did. Naturwiss. 2007, 13, 71-86.

37. Gräber, W.; Lindner, M. Interessenstudie Chemieunterricht: Vergleich 1990-2008 [Interest study chemistry education: Comparison 1990-2008]. In Chemie- und Physikdidaktik für die Lehramtsausbildung; Höttecke, D., Ed.; Lit: Münster, Germany, 2009; pp. 93-94.

38. Gutefrage. Available online: www.gutefrage.net/faq (accessed on 25 July 2018). 
39. Schratz, M.; Iby, M.; Radnitzky, E. Qualitätsentwicklung-Verfahren, Methoden, Instrumente [Quality Development_-Procedures, Methods, Instruments]; Beltz: Weinheim, Germany, 2000.

40. Gutefrage. Available online: www.gutefrage.net (accessed on 28 February 2019).

41. Davis, F.D.; Bagozzi, R.P.; Warshaw, P.R. User acceptance of computer technology: A comparison of two theoretical models. Manag. Sci. 1989, 35, 982-1003. [CrossRef]

42. Raymond, E.S.; Moen, R. How to Ask Questions the Smart Way 2014. Available online: tty1.net/smartquestions_de.html\#intro (accessed on 22 November 2016).

43. Stuckey, M.; Hofstein, A.; Mamlok-Naaman, R.; Eilks, I. The meaning of ,relevance' in science education and its implications for the science curriculum. Stud. Sci. Educ. 2013, 49, 1-34. [CrossRef]

(C) 2019 by the authors. Licensee MDPI, Basel, Switzerland. This article is an open access article distributed under the terms and conditions of the Creative Commons Attribution (CC BY) license (http://creativecommons.org/licenses/by/4.0/). 